\title{
IAPSO: tales from the ocean frontier
}

\author{
Denise Smythe-Wright ${ }^{1}$, W. John Gould ${ }^{1}$, Trevor J. McDougall ${ }^{2}$, Stefania Sparnocchia ${ }^{3}$, and \\ Philip L. Woodworth ${ }^{4}$ \\ ${ }^{1}$ National Oceanography Centre, Southampton SO14 3ZH, Hampshire, UK \\ ${ }^{2}$ School of Mathematics and Statistics, University of New South Wales, Kensington, NSW 2052, Australia \\ ${ }^{3}$ CNR Istituto di Scienze Marine, 34149 Trieste, Italy \\ ${ }^{4}$ National Oceanography Centre, Liverpool, L3 5DA, Merseyside, UK \\ Correspondence: Denise Smythe-Wright (dsw@noc.ac.uk)
}

Received: 13 November 2018 - Revised: 14 February 2019 - Accepted: 15 February 2019 - Published: 16 April 2019

\begin{abstract}
Our 21st century perspective on the oceans is due to the realization that knowledge of them and specifically their role in earth's climate are central to determining the future health of our planet. This present knowledge of the oceans builds on the farsighted work of people who, over the past century, worked to address seemingly intractable problems. The International Association for the Physical Sciences of the Oceans (IAPSO) has, over that long time span, promoted and supported the international approach that is now commonplace and has championed the provision of cross-cutting activities, the value of which we now fully recognize. This paper describes the key events in IAPSO's history and the roles played by the scientists involved.
\end{abstract}

\section{Introduction}

Until about 100 years ago the science of oceanography was primarily the profession of a small number of people, almost all of them men, who devoted their energy and skill, and often their own money, to understand the complicated motion of the sea and the lives of its creatures. In the midto late 1700s Benjamin Franklin gave us knowledge of the Gulf Stream and currents off the Atlantic coast of the USA. One hundred years later Matthew Fontaine Maury published The Physical Geography of the Sea (Maury, 1855) using data from ships' logbooks that recorded ocean temperature and the speed and direction of winds and currents in the North Atlantic. He also began direct measurements by asking sailors to put messages in bottles, giving the time and location when the bottle was launched and asking the finder to report back to him where and when the bottle was washed ashore. In this way he was able to further refine his charts and maps.

The situation changed with the worldwide voyage of $H M S$ Challenger which set out to specifically make systematic measurements of ocean parameters between 1872 and 1876 . However, HMS Challenger was not the only vessel to be making measurements around this time. Many national vessels including the French naval vessels the Travailleur and the Talisman and the German Gazelle were making biodiversity and hydrographic measurements, and it was after seeing the findings from the two French vessels in an exhibition at the Paris Museum that HMSH Prince Albert I of Monaco made a decision in 1884 to devote his time and resources to oceanography. Having served in the French and Spanish navies as a young man, he had a profound interest in the sea. Over the subsequent 30 years, he financed and used four increasingly impressive research yachts the $\mathrm{Hi}$ rondelle, Princesse Alice, Princesse Alice II, and Hirondelle II to make numerous oceanographic measurements, maps and charts. Initially his main collaborators were Baron Jules de Guerne and Jules Richard, and later he was joined by John Young Buchan after he had completed his service as a chemist with the Challenger expedition, where HMSH Prince Albert I also worked with Maurice Leger and Paul Portier to develop scientific equipment. He even used drift bottle measurements like Maury had to determine the splitting of the Gulf Stream, showing one branch heading north towards northern Europe and the other heading south past Spain and Africa before turning back west. His last voyage ended in 1914 with the outbreak of World War I, but he continued to advise military officials on how explosive mines would drift in the ocean and where they would land. 

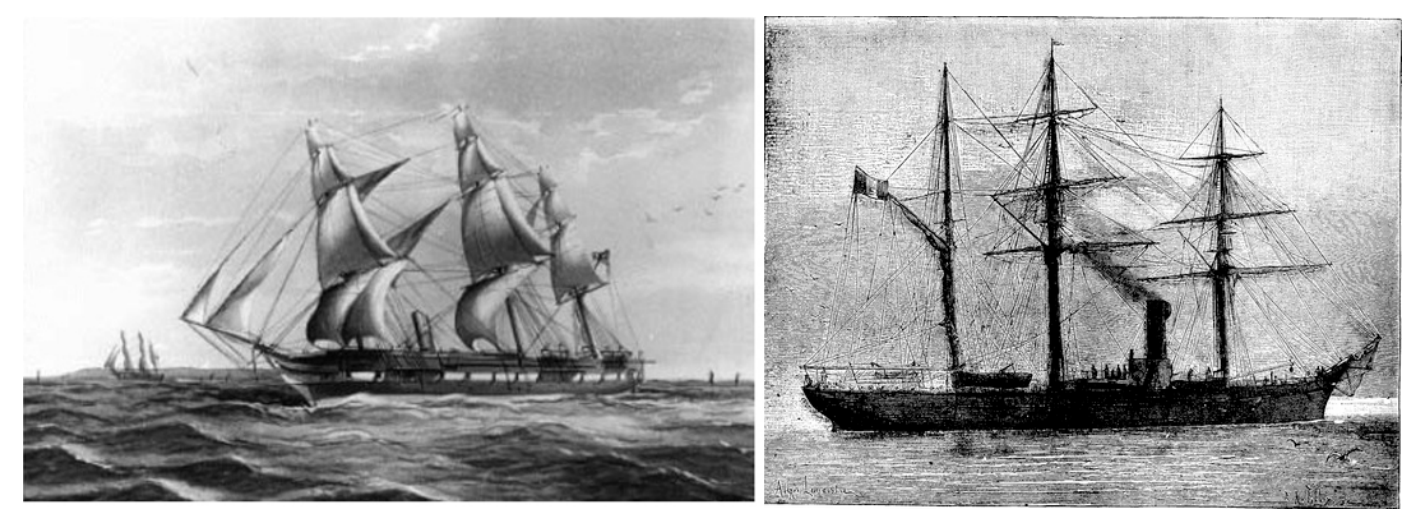

Figure 1. HMS Challenger (source: https://en.wikipedia.org/wiki/Challenger_expedition (last access: 19 March 2019) and the French scientific steamer, the Talisman (source: https://commons.wikimedia.org/wiki/File:THE-FRENCH-SCIENTIFIC-STEAMER-TALISMAN.png, last access: 19 March 2019).

\section{IAPSO history}

\subsection{In the beginning}

As a result of the plethora of ocean measurements being undertaken at the end of the 19th century by individual countries, leading scientists began to advocate the need to pool data and resources for further measurement, to get the best possible understanding - an ideal that has not changed during the last 100 years.

The political arena at the time was very different from what it is today and there was much friction between countries and individual scientists. However, goodwill prevailed and in 1902 the International Council for the Exploration of the Sea (ICES) was established. Its remit was to cover the North Sea, the Baltic Sea, the Norwegian Sea, and the Barents Sea. There had been discussion at a preliminary meeting in 1899 to include measurements in the North Atlantic, supported by the marine stations on oceanic islands such as the São Miguel island in the Azores. It was proposed that these measurements would be combined with the work of HMSH Prince Albert I (Commission Hydrographique Suédoise, 1899). This suggestion was not taken up and the Atlantic investigation was confined to a small region northwest of Scotland. Nevertheless, it was still felt to be imperative for the understanding of the oceanography and fisheries of the marginal seas to have regularly occupied hydrographic stations in the open Atlantic Ocean. It was generally agreed that this was one of the most pressing issues in oceanography. Consequently, following the Ninth International Geographic Congress in 1908, the International Commission for the Scientific Exploration of the Atlantic was established alongside a similar commission for the Mediterranean, and HMSH Prince Albert I of Monaco became the chairman of both commissions.

During the following 2 years the members of the two commissions were selected, and meetings were held in Monaco in 1910 in connection with the inauguration of the Musée
Océanographique. At these meetings, detailed plans for a study of the Atlantic were discussed (Berget, 1910). However, the Atlantic Commission did not meet again whereas the Mediterranean Commission (Commission Internationale pour l'Exploration Scientifique de la mer Méditerranée, CIESM) is still in existence.

At the end of World War I, with the encouragement of John Buchan, HMSH Prince Albert I sought to establish an international organization for oceanography. He had always had a strong interest in international cooperation; in 1900, prior to his chairmanship of the Atlantic and Mediterranean commissions, he had granted his patronage to the establishment of the short-lived International Marine Association, the last meeting of which was in 1904. The opportunity arose in July 1919 during the Constitutive Assembly of the newly formed International Research Council when it decided to form the International Union of Geodesy and Geophysics (IUGG) as a union of six sections. One of the sections was assigned to physical oceanography, dealing with tides, currents, temperature, salinity, and other physical phenomena of the oceans, and HMSH Prince Albert I took on the role of its first president. The physical oceanographers did not accept biology being part of their section, but this proved to be of no consequence after HMSH Prince Albert I founded a biological oceanographic section under the umbrella of the International Union of Biological Sciences and became its first president.

\subsection{The early years}

With HMSH Prince Albert I as president, the applied mathematician Horace Lamb of the UK as vice president, and Giovanni Magrini of Italy as secretary, the Section for Physical Oceanography held its first General Assembly in Paris in 1921. The scope of the section was detailed as follows:

- morphology of the sea bottom, 


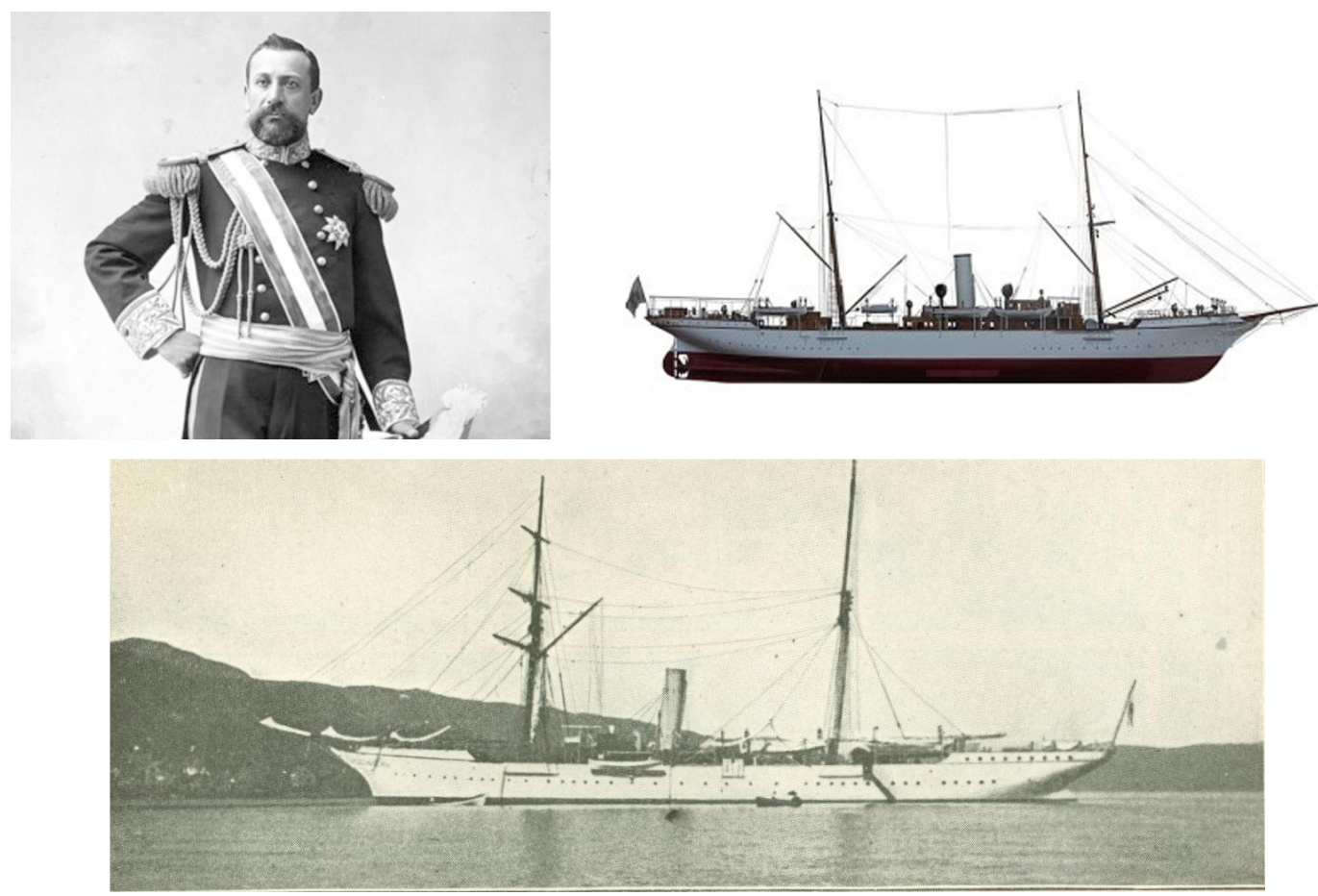

Figure 2. HMSH Prince Albert I of Monaco and his vessels the Hirondelle (top; source: http://www.institut-ocean.org/, last access: 19 March 2019) and Princesse Alice (bottom; source: http://www.digitalhistoryproject.com/2012/08/prince-albert-of-monaco-as-oceanographer.html, last access: 19 March 2019).

- morphology of the surface of the oceans and seas,

- movements of the water masses, and

- physical and chemical studies of seawater.

Here it was suggested that special committees for the study of the Atlantic Ocean and Pacific Ocean be established, but this was postponed due to concerns over conflicts of interests between countries and scientists (Smed, 2007). In 1921 Otto Pettersson suggested that ICES and the Section for Physical Oceanography regarded each other with dignified reserve "comme deux chiens de porcelaine sur une cheminée" (Pettersson, 1921).

Very soon after the first IUGG assembly held in Rome in May 1922, HMSH Prince Albert I died, and so in July 1922 Vice Admiral Sir John Perry from the UK, who had been elected vice president at the Rome assembly, carried on until the next IUGG General Assembly held in Madrid in 1924. At this time, Odon de Buen of Spain was elected president and Vice Admiral Perry and Magrini continued as vice president and secretary, respectively. However, Vice Admiral Perry died in 1926 and de Buen and Magrini carried on until they were re-elected to their positions at the third IUGG General Assembly held in Prague, Czechoslovakia, in 1927, and Johannes Schmidt of Germany became vice president.

\footnotetext{
${ }^{1}$ Like two porcelain dogs on a fireplace.
}

Throughout these years the Atlantic and Pacific special committees had still not been established, but a tidal committee had emerged. In reality, research in the Atlantic was being carried out by ICES, the International Ice Observation and Ice Patrol (forerunner of the US Coast Guard), and the North American Committee on Fishery Investigations. The International Committee on the Chemical and Physical Oceanography of the Pacific, founded in 1923, was responsible for measurements in that ocean.

At an assembly in Seville, Spain, in 1929, held separately from IUGG, the Section for Physical Oceanography adopted the term "Association". This was in line with the proposed reorganization of the International Research Council, which became the International Council of Scientific Unions (ICSU) in 1931. At the fourth IUGG General Assembly held in Stockholm, Sweden, Martin Knudsen of Denmark was elected president, Eugène Fichot of France became vice president, and Rolf Witting of Finland became secretary, while de Buen and Magrini continued as members of the executive committee. At this meeting some preliminary discussions about the Association's statutes and bye-laws began (ProcèsVerbaux, 1934), but these were not adopted until 1933, when all the former sections of the IUGG became international associations and were authorized to set up their own statutes.

At the fifth IUGG General Assembly held in Lisbon, Portugal, in 1933, Knudsen and Fichot were re-elected to their positions and Joseph Proudman from the UK became secre- 


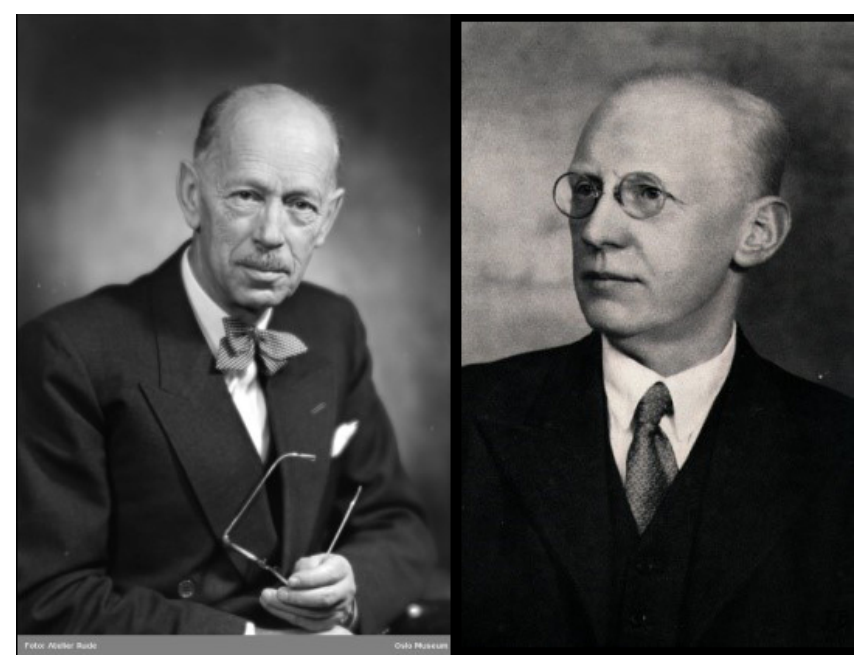

Figure 3. Professors Harald Sverdrup (source: https: //digitaltmuseum.org/011014857601/harald-sverdrup/media? slide $=0$, last access: 19 March 2019) and Joseph Proudman (source: http://www.tide-and-time.uk/local-heroes-joseph-proudman, last access: 19 March 2019).

tary (he held that position until 1948). Magrini and de Buen continued on the executive committee but Magrini died in 1935. At this assembly it was decided that what was formerly known as the International Association of Physical Oceanography (IAPO) should mainly deal with those parts of oceanography in which mathematics, physics, and chemistry were used for the scientific study of the sea - a situation that continues today. The Atlantic and Pacific committees of the former oceanography section were abolished, but the committee on tides survived.

\subsection{The middle years}

General assemblies were held in 1936 in Edinburgh, Scotland, and in September 1939 in Washington, D.C. Bjørn Helland-Hansen became president of the Association in 1936 and held that position until 1946 when Harald Sverdrup became president, continuing in that position until 1951.

Due to the disruptions of World War II (WWII), no general assembly was held from 1940 until 1948 when it was in Oslo, Norway. In 1948 Proudman became vice president and Håkon Mosby of Norway became secretary. In 1951 Proudman became president of the Association and had great influence on its development. Back in 1930, he had strongly argued against governmental and non-governmental oceanographic organizations coming together and also against close collaboration between physicists and biologists. He felt that the admission of biologists would cause difficulties and should be avoided in the interest of science. He never changed his opinion - some would say to the detriment of IAPO as we are now acutely aware that some of the big is- sues such as climate change and ocean acidification cannot be addressed without biologists.

In many ways, WWII was a turning point; the importance of submarine operations and the prediction of conditions on landing beaches provided an impetus that continued into the post-war era and highlighted the inherent variability of the oceans. Since then much more effort has been devoted to marine science. As the science developed, oceanographic institutions were established worldwide and these organizations dealt not only with marine physics, but also with marine chemistry, biology, and geology and geophysics. This resulted in the creation of a Special Committee on Oceanic Research, later to become the Scientific Committee on Oceanic Research (SCOR), in 1957; this coincided with the International Geophysical Year 1957-1958. SCOR became a great success and it is not surprising that there was some friction between IAPO and SCOR.

Historical papers suggest that the General Assembly in Helsinki, Finland, in 1960 was one of note. Subsequent correspondence suggests that the weather was unbearably hot and the venue airless and stifling, causing many either to lose attention or fall asleep as well as divesting themselves of as much clothing as decently possible. Nevertheless, the papers show that at this time IAPO was a thriving organization with committees on tides, sea level, bibliographic classification, chemical oceanography, and the General Bathymetric Chart of the Oceans (GEBCO). The GEBCO committee became one of IAPO's greatest successes. They instigated updated editions of early charts, which had been compiled initially by the Cabinet Scientifique of HMSH Prince Albert I, by working with the International Hydrographic Bureau in obtaining soundings from multiple hydrographic offices worldwide and the World Data Centres, and making decisions about projection, scale, and other parameters. GEBCO continues to this day but under the auspices of the International Hydrographic Organization and the Intergovernmental Oceanographic Commission (IOC) of the United Nations Educational, Scientific and Cultural Organization (UNESCO).

In 1967, IAPO proposed that ICSU integrate all its organizations with an interest in the sea by creating an International Union of Marine Sciences, but this met with opposition, mainly from those who thought that unions should be organized by discipline rather than be interdisciplinary (Charnock, 1984). After much argument the ICSU decided against the proposal and the physical oceanographers changed the name of their Association to the International Association for the Physical Sciences of the Ocean (IAPSO) and broadened its scope to include commissions on marine geophysics and on marine chemistry as well as on physical oceanography. An amicable and constructive arrangement with SCOR was reached, whereby IAPSO continued to provide a forum for international meetings and maintaining standards and methods, and SCOR promoted bottomup research funding projects and working groups proposed by the research community. The president of IAPSO became 
an ex-officio member of the SCOR Executive Committee, and over the years subsequent IAPSO presidents have contributed to the running of SCOR and the decisions it makes. In return, many of the IAPSO successes have been in collaboration with SCOR.

In 1970, as IAPSO reached its half century, it held its 15th Scientific Assembly alongside the scientific sessions of SCOR's Joint Oceanographic Assembly in Tokyo. It was arranged by the Science Council of Japan, under the title "The Ocean World". Symposia were organized in cooperation with the International Association of Geochemistry and Cosmochemistry (IAGC), the Scientific Committee on Antarctic Research (SCAR), and the Upper Mantle Committee (UMC). The meeting was also sponsored by the International Association of Volcanology and Chemistry of the Earth's Interior (IAVCEI), UNESCO, the World Meteorological Organization (WMO), and the Food and Agriculture Organization of the United Nations (FAO). It was a truly multidisciplinary event with scientific sessions covering all aspects of oceanography.

In 1983, at the General Assembly in Hamburg, IAPSO set up a Commission for Oceanographic Advice to Developing Countries; it later changed its name to the Commission for Oceanographic Cooperation with Developing Countries. It was chaired by Eugene La Fond and one of its first tasks was to organize a workshop entitled Oceanographic Advice to Developing Countries at the General Assembly in 1985 in Vancouver. It also organized another workshop on physical oceanography at the SCOR meeting in Acapulco in 1988. In the hope of fostering marine science in developing countries by improving the quality of scientific papers, the IAPSO Executive Committee approved the commission's suggestion that an award be given for the best scientific presentation by a scientist from a developing country. Gold-coloured medals were cast and two were awarded at the IAPSO Plenary Session of the IUGG General Assembly in Vienna in 1991 to Dindi Satyanarayan and to Ye Longfei, because the two presentations were found to be of equally high quality. These activities started a long-standing commitment by IAPSO to assist scientists in developing countries. Today the Association provides a large number of grants to scientists from these countries.

\subsection{Modern IAPSO}

The IAPSO that we know today really emerged in 1995 . That year IAPSO held its General Assembly in Honolulu in August and it was the largest in the history of IAPSO, involving the greatest number of countries. Led by President Robert Muench, preparations had been in place for over 3 years, including implementation of an up-to-date database of all working oceanographers on the IAPSO mailing list and making the assembly known to them. At the end of this assembly Vere Shannon from South Africa was elected president and Fred Camfield from the USA took over as secretary general,

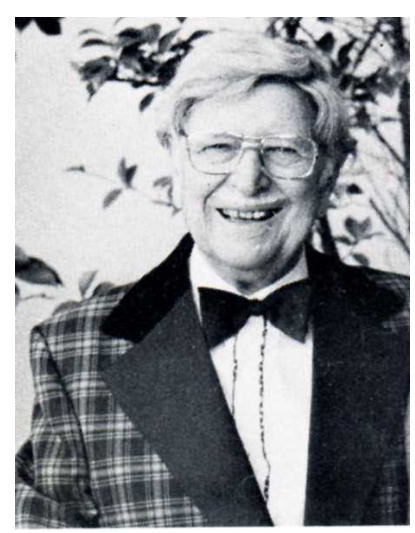

Figure 4. Eugene La Fond (source: IAPSO archives).

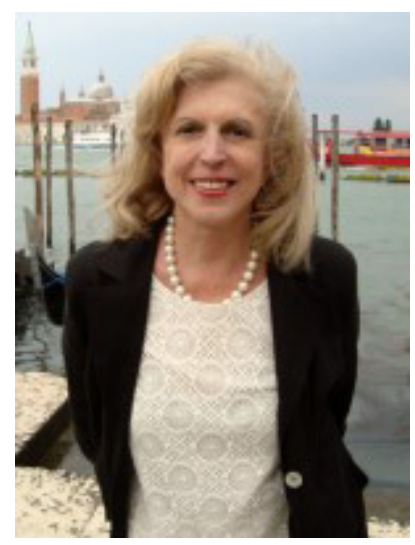

Figure 5. Paola Malanotte-Rizzoli (source: IAPSO archives).

with the title of secretary having changed to secretary general in 1979. During 1996, Camfield established the IAPSO web pages and instigated direct responses to various enquiries received by letter, email, or facsimile. Throughout his time as president, Shannon worked on a strategy document for the Association that was ultimately finalized and distributed in 2004 when some revisions to the statues and bye-laws were made. Shannon was keen to raise the profile of IAPSO and to include more chemistry and biology, so it was agreed that the 2001 assembly would be in Mar del Plata, Argentina, as a joint venture with the International Association for Biological Oceanography (IABO).

Following the 1997 assembly the secretary general posted the details and abstracts of the IAPSO symposia and IAPSOled joint symposia on the website and this has continued to date. It has proved to be a valuable resource to the scientific community with many hits well after the assemblies have finished.

At the end of the IUGG assembly in 1999, Paola Malanotte-Rizzoli became the first female IAPSO president and a chemist, Denise Smythe-Wright, joined the executive committee; representation of this discipline of oceanography had been somewhat short over the years. In addition, the As- 


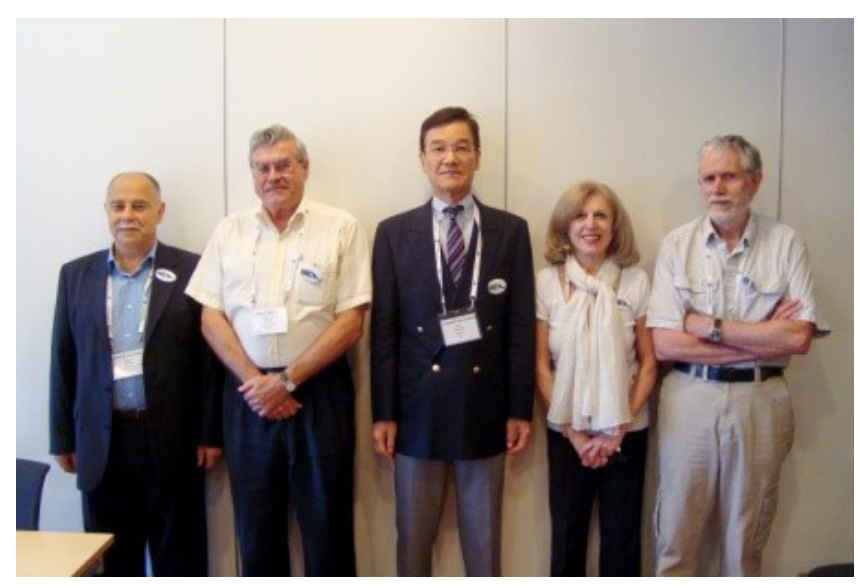

Figure 6. Five recent presidents of IAPSO: Eugene Morozov, Lawrence Mysak, Shiro Imawaki, Paola Malanotte-Rizzoli, and Robin Muench (source: IAPSO archives).

sociation changed its name from the International Association for the Physical Sciences of the Ocean to the International Association for the Physical Sciences of the Oceans (plural). It was also decided to instigate a medal award and the suggestion was made that this could be in memory of IAPSO's founder HMSH Prince Albert I.

The joint IAPSO/IABO assembly in 2001 proved to be very successful and a tentative suggestion was made to follow it up in 2005; this resulted in the joint IAPSO/IABO assembly in Cairns, Australia, in 2005, but sadly this example has not been repeated.

In 2007, a decision was made to encourage scientists from developing countries to join the executive committee and it was proposed to separate the duties of treasurer and secretary, which had been combined up until then. Consequently, at the 2007 General Assembly, Johan Rodhe became secretary general and the office moved from the USA to Sweden; Camfield continued as treasurer, a post he relinquished in 2013. Rodhe then went on to completely revise the IAPSO website and also produce publicity material to raise the IAPSO profile with the international community including the production of a pamphlet that was distributed at the 2007 meeting of the American Geophysical Union (AGU) in San Francisco and to worldwide organizations and delegates.

In the last decade, IAPSO has continued to hold biannual assemblies, maintain its commissions and services, and work with SCOR. In July 2015, Rodhe retired from his position as secretary general; the office moved to Italy, managed by the newly elected secretary general Stefania Sparnocchia; and Ken Ridgway from Australia was appointed treasurer.

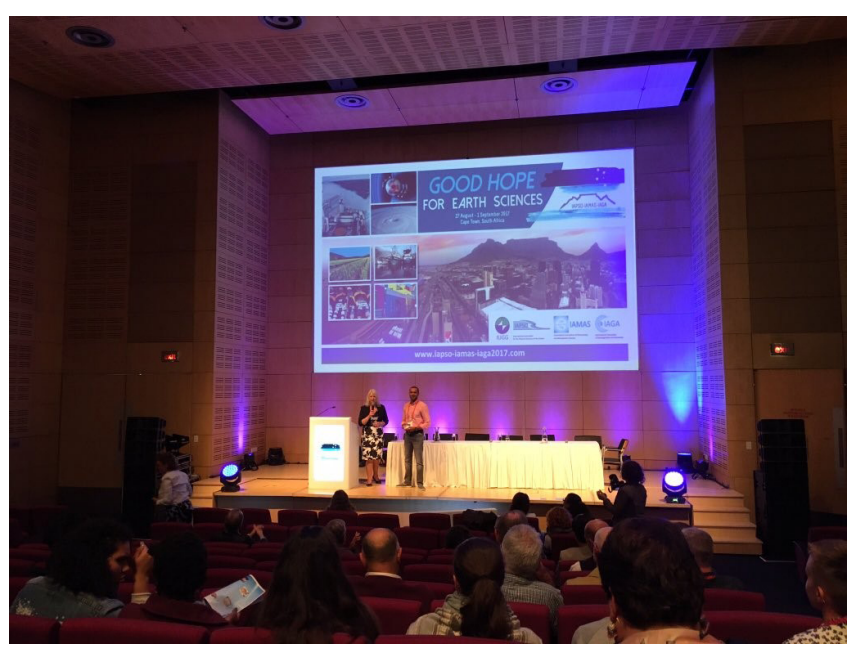

Figure 7. Presentation of the 2017 La Fond Medal to Johnathan Durgadoo (source: IAPSO archives).

\section{IAPSO awards}

In the last 15 years IAPSO has instigated two awards, the Prince Albert I Medal and the Eugene La Fond Medal. These are awarded every 2 years at IAPSO assemblies.

\subsection{Prince Albert I Medal}

Following the decision in 1999 to instigate a medal in memory of HMSH Prince Albert I, Paola Malanotte-Rizzoli, the IAPSO president at the time, wrote to HMSH Prince Rainier III of Monaco proposing the establishment of an award to recognize the pioneering and extraordinary contributions HMSH Prince Albert I made to and in support of physical oceanography. HMSH Prince Rainier III's answer was enthusiastic; he offered to present a most eminent scientist with a Medal for Excellence in the Physical Sciences of the Oceans. An official protocol was established and ratified by $\mathrm{HMSH}$ Prince Rainier III in February 2001. The medal is awarded to a most prominent scientist, chosen by a specially appointed IAPSO Award Committee, in recognition of the scientist's outstanding contributions to the enhancement and advancement of the physical and/or chemical sciences of the oceans.

\subsection{The Eugene La Fond Medal}

In 2003 the IAPSO Executive Committee decided to award a medal in memory of Eugene La Fond to a scientist born and primarily educated in a developing country. In deference to the 1991 award, it is given to the person who makes the best oral or poster presentation in an IAPSO-sponsored or co-sponsored symposium at an IUGG or IAPSO assembly. 
Table 1. IAPSO presidents, secretaries, and secretaries general.

\begin{tabular}{|c|c|}
\hline IAPSO presidents & IAPSO secretaries general \\
\hline 1919-1922 S.A.S. Prince Albert I (Monaco) & 1919-1930 Giovanni Magrini (Italy) \\
\hline \multicolumn{2}{|l|}{ 1924-1930 Odón de Buen (Spain) } \\
\hline 1930-1936 Martin Knudsen (Denmark) & $\begin{array}{l}\text { 1930-1933 Rolf Witting (Finland) } \\
\text { 1933-1948 Joseph Proudman (UK) }\end{array}$ \\
\hline \multicolumn{2}{|l|}{ 1936-1946 Bjørn Helland-Hansen (Norway) } \\
\hline \multicolumn{2}{|l|}{ 1946-1951 Harald U. Sverdrup (Norway) } \\
\hline & 1948-1954 Håkon Mosby (Norway) \\
\hline \multicolumn{2}{|l|}{ 1951-1954 Joseph Proudman (UK) } \\
\hline \multirow[t]{2}{*}{ 1954-1960 Håkon Mosby (Norway) } & 1954-1957 Richard H. Fleming (USA) \\
\hline & 1957-1963 Börje Kullenberg (Sweden) \\
\hline \multicolumn{2}{|l|}{ 1960-1963 George E. R. Deacon (UK) } \\
\hline 1963-1967 Roger Revelle (USA) & 1963-1967 Ilmo Hela (Finland) \\
\hline 1967-1970 Günter Dietrich (F.R. Germany) & 1967-1970 Arthur E. Maxwell (USA) \\
\hline 1970-1975 Henri Lacombe (France) & 1970-1987 Eugene C. LaFond (USA) \\
\hline \multicolumn{2}{|l|}{ 1975-1979 Robert W. Stewart (Canada) } \\
\hline \multicolumn{2}{|l|}{ 1979-1983 Devendra Lal (India) } \\
\hline \multicolumn{2}{|l|}{ 1983-1987 Wolfgang M. Krauss (F.R. Germany) } \\
\hline 1987-1991 James J. O’Brien (USA) & 1987-1995 Robert E. Stevenson (USA) \\
\hline \multicolumn{2}{|l|}{ 1991-1995 Robin D. Muench (USA) } \\
\hline 1995-1999 L.Vere Shannon (South Africa) & 1995-2007 Fred E. Camfield (USA) \\
\hline \multicolumn{2}{|l|}{ 1999-2003 Paola Rizzoli (Italy/USA) } \\
\hline \multicolumn{2}{|l|}{ 2003-2007 Shiro Imawaki (Japan) } \\
\hline 2007-2011 Lawrence Mysak (Canada) & 2007-2015 Johan Rodhe (Sweden) \\
\hline \multicolumn{2}{|l|}{ 2011-2015 Eugene G. Morozov (Russia) } \\
\hline 2015-2019 Denise Smythe-Wright (UK) & 2015-2021 Stefania Sparnocchia (Italy) \\
\hline
\end{tabular}

\section{Commissions and services}

In fulfilling its role to study the scientific problems relating to the ocean and the interactions taking place at its boundaries, IAPSO has sponsored or co-sponsored many commissions and services, some with IUGG and some with other associations of the IUGG family; these are detailed on the IAPSO website (http://iapso.iugg.org/, last access: 19 March 2019). IAPSO has three current commissions, listed as follows.

- The Joint Committee on the Properties of Seawater (JCS) is a permanent group with limited membership that acts as an international point of contact for questions relating to seawater and maintains a repository of knowledge and software for the scientific community via the website http://www.teos-10.org/ (last access: 19
March 2019). It is jointly sponsored by IAPSO, SCOR, and the International Association for the Properties of Water and Steam (IAPWS) and provides a conduit for communication between its parents and other international organizations such as the Bureau International des Poids et Mesures (BIPM), WMO, and the International Union of Pure and Applied Chemistry (IUPAC). In addition, JSC makes suggestions where gaps exist in available knowledge.

- The Commission on Mean Sea Level and Tides (CMSLT) supports research into applications of sea level measurements. Its membership is open to any researcher with an interest in mean sea level and tides. In addition 
Table 2. The Prince Albert I Medal winners to date (source: IAPSO archives).

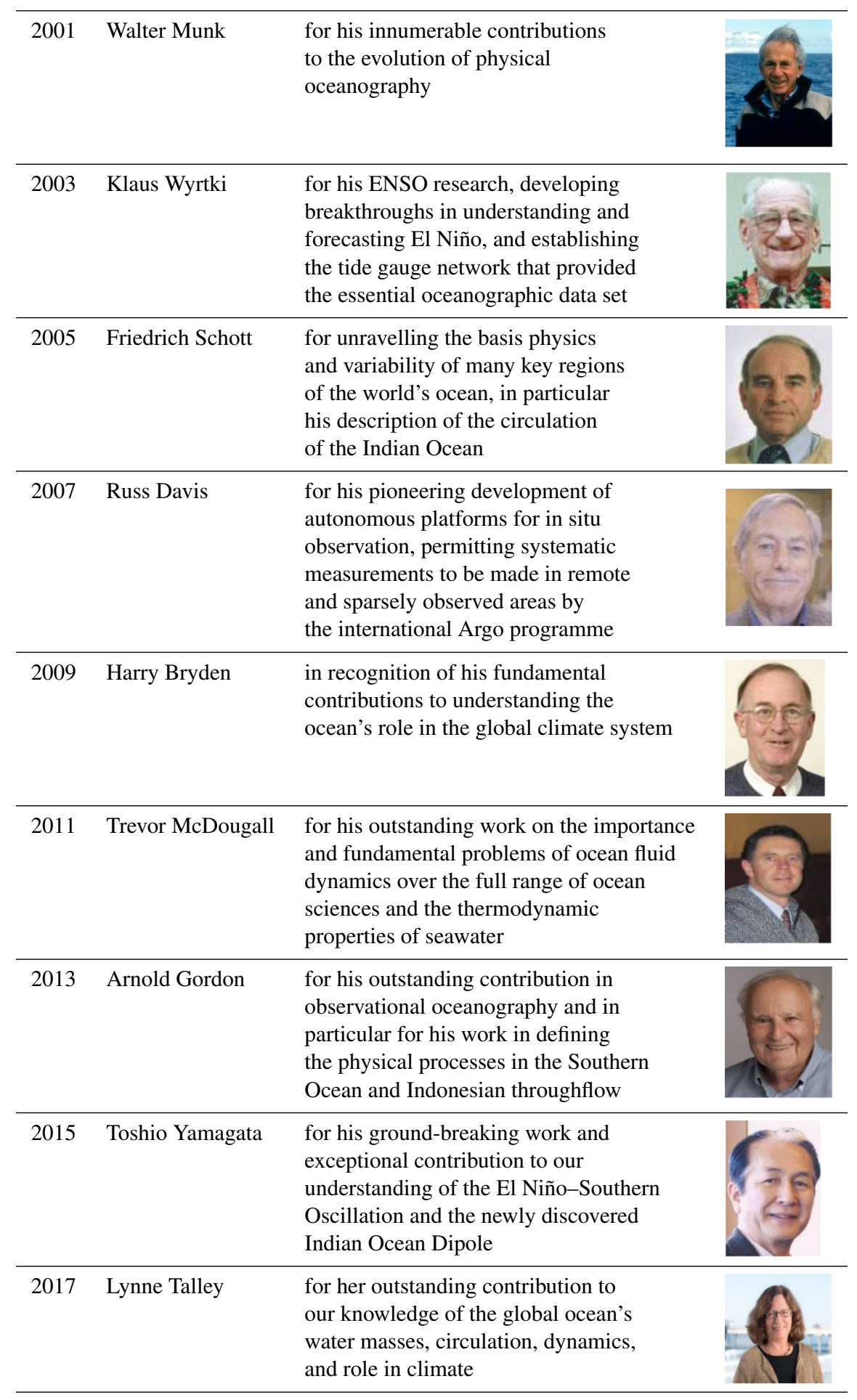

to sponsoring meetings, the CMSLT is the body responsible for the Permanent Service for Mean Sea Level.

- The Tsunami Commission is responsible for international coordination of tsunami-related meetings, re- search, and publications. It is a long-standing commission established in 1960 to promote the exchange of scientific and technical information about tsunamis, including an improved understanding of the dynamics of generation, propagation, coastal run-up and the conse- 
Table 3. Recipients of the Eugene La Fond Medal to date.

\begin{tabular}{lll}
\hline Year & Recipient & Title of presentation \\
\hline 2003 & Margarita V. Chikina, Russia & $\begin{array}{l}\text { Influence of Mesoscale Circulations on the Coastal Benthic Communities } \\
\text { in the Black Sea }\end{array}$ \\
\hline 2005 & Maria del Carmen Grados, Peru & $\begin{array}{l}\text { ENSO impacts in the northern boundary of the Humboldt ecosystem } \\
\text { during 1960-2005 }\end{array}$ \\
\hline 2007 & Catia Motta Domingues, Brazil & Towards more accurate estimates of the thermosteric sea level rise \\
\hline 2009 & Bamol A. Sow, Senegal & $\begin{array}{l}\text { Simulation of the Senegalese and Mauritanian Upwelling: How are the } \\
\text { Winds actually Driving SST Variability and Water Mass Renewal? }\end{array}$ \\
\hline 2011 & Towhida Rashid, Bangladesh & Holocene relative sea level change in Bangladesh \\
\hline 2015 & Sana Ben Ismail, Tunisia & $\begin{array}{l}\text { Eddy properties in the Mozambique Channel: a comparison between } \\
\text { observations and two numerical ocean circulation models }\end{array}$ \\
\hline 2017 & Jonathan Durgadoo, Mauritius & Indian Ocean sources of Agulhas leakage \\
\hline
\end{tabular}

quences to society of the tsunami hazard; something that has become particularly relevant in recent years.

IAPSO also has the following two services.

- The Permanent Service for Mean Sea Level (PSMSL) is the internationally recognized global sea level data bank for long-term sea level change information from tide gauges and also provides a wider service to the sea level community.

- The Standard Seawater Service is the only internationally recognized organization for the calibration of salinity measurement devices. Its widespread use over 100 years of IAPSO history has been of great importance to the quality and comparability of salinity data worldwide.

\subsection{The Permanent Service for Mean Sea Level}

Spatial and temporal changes in mean sea level were discussed at a meeting of IAPO at the 5th General Assembly of the IUGG in Lisbon in 1933. Rolf Witting and Joseph Proudman were the national delegates from Finland and the UK, respectively. Witting was a distinguished Baltic oceanographer and had founded the Finnish Institute of Marine Research in 1918. By 1933, he was also a politician and government minister, and he would go on to be Finnish Foreign Minister in the wartime government.

Witting appreciated the importance of sea level measurements for understanding ocean circulation. In particular, he had an interest in determining the mean dynamic topography of the Baltic Sea by measuring spatial differences between mean sea level recorded at many stations with respect to a common levelling datum (the geoid, in effect). To do that he had to make corrections for glacial isostatic adjustment (then known as post-glacial rebound), which meant that he had to collect time series of relative sea-land levels using tide gauge data.

Proudman had already been active in IAPO for many years. He was nominated secretary of an IUGG Mean Sea Level Committee and set about collecting monthly and annual values of mean sea level using the international contacts of the International Hydrographic Bureau. At an IAPO meeting in 1936, it was decided that the collection should be made available as widely as possible and be published in special volumes. The first such volume was published by Proudman in 1940 as one of the IAPO Publications Scientifiques series (IAPO, 1940), and it did not take long for someone to use it to produce the first of many scientific papers on sea level changes using these data (Gutenberg, 1941). In 1951, the terms of reference of the committee were extended to have it report regularly on secular variations in mean sea level around the world.

This brings us to 1958, around the time of the International Geophysical Year. At this point, it was decided that, for several reasons, the Mean Sea Level Committee would be better constituted as a "permanent service" of ICSU. It was considered that having a clearly defined home for the service would provide it with greater financial stability and that the name Permanent Service for Mean Sea Level would provide the necessary international authority. In view of Proudman's close association with the committee, the Tidal Institute of the University of Liverpool, of which Proudman was director, was asked to host it (Rossiter, 1963). Formally, the PSMSL is now a service of the IUGG as a whole: IAPSO provides its main Association link (and the IAPSO Commission on Mean Sea Level and Tides serves as its governing board) while the 

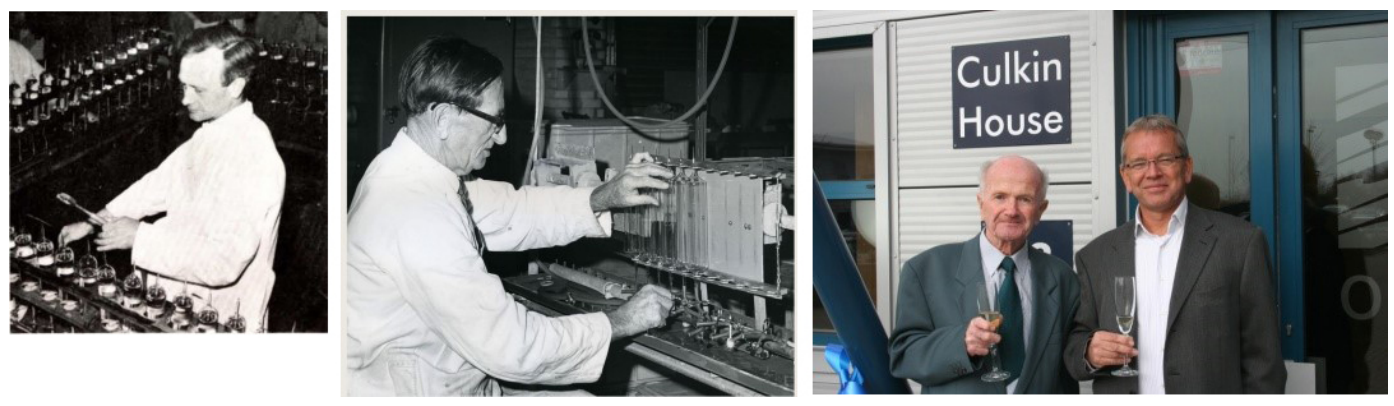

Figure 8. From the early days of Frede Hermann, through IOS to OSIL (source: UK National Oceanography Archives and OSIL).

International Association of Geodesy (IAG) also considers the PSMSL to be one of its services.

As a result of the changes in 1958, the terms of reference of the PSMSL were expanded further. In particular, the service was to encourage the development of a global network of sea level stations and to engage in its own research. Otherwise, the work remained largely the same as that of the committee and has remained so ever since, in spite of many technical developments in data collection, storage, and dissemination. The PSMSL now holds over 70000 station years of information from around the world with more than 300 records 60 years or longer in the Revised Local Reference subset (stations with datum continuity). The dataset is used by many scientists throughout geophysics, and the provision of those data to users remains the PSMSL's main role.

Between 2012 and 2016, over 330 peer-reviewed papers were published in 97 distinct journals, and the number of citations has increased every year to around 70 citations per year. PSMSL staff also produce their own papers, partly as a means of providing a high-level quality control to the dataset. Papers that make use of PSMSL data are always prominent in the sea-level-related chapters of the research assessments of the Intergovernmental Panel on Climate Change (IPCC).

In recent years, considerable efforts have been put into providing a much-improved website enabling users to find where in the world data exist and the properties of each time series (trends together with uncertainty estimates, anomalies, etc.). In addition, PSMSL is working with other sea level centres to improve data interoperability between data streams and enable closer integration of the mean sea level data set with higher-frequency data. There are also links to records of land movements obtained by Global Navigation Satellite System (GNSS) equipment. PSMSL has started providing data from in situ ocean bottom pressure recorders from all possible sources, fulfilling a remit given to the PSMSL by IAPSO in 1999.

The PSMSL has continued serving the wider sea level community, providing training materials, organizing training courses for developing countries, and playing a major role in the development of the Global Sea Level Observing System (GLOSS) of the IOC of UNESCO. Many more details on the PSMSL's present-day activities can be found on its web site (https://www.psmsl.org/, last access: 19 March 2019) or in publications (e.g. Holgate et al., 2013; Woodworth and Rickards, 2014).

An important point to stress is that, back in 1933, when the original Mean Sea Level Committee was set up, no one knew the uses to which its sea level data would be put many years later. It is clear that a permanent global network of good sea level measuring stations is required, along with the data bank infrastructure to support it such as presently provided by the PSMSL, in order to ensure that future scientists have the data that they need, even if they are not in the applications we think are important now (Nature Geoscience Editorial, 2013).

\subsection{The Standard Seawater Service}

In the global-scale science of oceanography the challenge of documenting subtle climate-related changes requires wellestablished and accepted standards. While those for temperature and pressure are universal, marine science has had to establish its own standards for salinity. Thanks to farsighted individuals and to the underpinning support of IAPSO those standards have been maintained for over a century.

By the time IUGG was founded, the concept of salinity had been developed by Scandinavian scientists and the constancy of seawater's chemical composition had been confirmed by Dittmar's analysis of samples from the 1870s HMS Challenger expedition (Dittmar, 1884). It was also known that the measurement of the chlorinity of samples, by titration against silver nitrate, could be the basis for determining salinity. By the turn of the century many laboratories were making observations of temperature and salinity, and one of the initial roles of ICES was to coordinate these. ICES recognized that the only practical way to ensure that all salinity measurements were consistent would be to distribute "standard" seawater samples to all researchers. Starting in 1908 Martin Knudsen in Copenhagen assumed responsibility for what became known as the ICES Standard Seawater Service.

And so the service continued to distribute carefully prepared batches of water until Knudsen's retirement in 1947 (at the age of 76). He then concluded that the service needed 
to be overseen by a well-respected global-scale scientific organization, and so it came about that from 1948 the service became the responsibility of IAPSO.

Standard seawater was produced and distributed from Denmark under first Helge Thomsen's and then Frede Hermann's guidance until 1975 when with IAPSO's support the operation transferred to the UK Institute of Oceanographic Sciences (IOS) under the direction of Fred Culkin (Culkin and Smed, 1979). Shortly thereafter the production and distribution operations of the Standard Seawater Service became a self-sustaining commercial activity, continued from 1989 to the present day by Ocean Scientific International Limited (OSIL; https://osil.com/, last access: 19 March 2019).

IAPSO's links with salinity determination have been firmly rooted in the changing understanding of salinity as a fundamental physical property. In 1978 the concept of salinity moved away from the earlier chemical (chlorinity) basis to one linked to electrical conductivity (PSS-78), and most recently IAPSO-sponsored research has led to the thermodynamically defined Absolute Salinity (Millero et al., 2008).

In the 70 years since IAPSO assumed oversight responsibility for the Standard Seawater Service, marine science has changed beyond recognition - from observational techniques that were established in the late 19th century to the presentday world of robotic recording instruments. Throughout these changes IAPSO's support of this fundamental service to the marine science community has been unswerving.

\section{Relationship with SCOR}

Each year SCOR approves new working groups (WGs) and the IAPSO Executive Committee is involved in promoting and evaluating the proposals. IAPSO has also cofunded some very successful groups. One of the earliest was WG 10 - Oceanographic Tables and Standards - which became the Joint Panel on Oceanographic Tables and Standards (JPOTS). The recent working groups are listed as follows:

- IAPSO/SCOR Joint Working Group 121 on Ocean Mixing (2002-2004),

- SCOR/LOICZ/IAPSO Working Group 122 on Mechanisms of Sediment Retention in Estuaries (2003-2005),

- SCOR/IAPSO Working Group 127 on Thermodynamics and Equation of State of Seawater (2005-2009),

- SCOR/IAPSO Working Group 129 on Deep Ocean Exchange with the Shelf (DOES) (2006-2008),

- SCOR/IAPSO Working Group 133 OceanScope (20082011), and

- SCOR/WCRP/IAPSO Working Group 136 Climatic Importance of the Greater Agulhas System (20092012).
Possibly the most successful was WG 127 . This was instigated by the IAPSO community and resulted in fundamental changes to the equation of state of seawater as defined by TEOS-10 (TEOS-10, IOC et al., 2010). It involved the introduction of the Gibbs potential function for seawater and a new salinity formulation called Reference Salinity $\left(S_{\mathrm{R}}\right)$ expressed in $\mathrm{g} \mathrm{kg}^{-1}$.

Another IAPSO-instigated SCOR working group, the SCOR/WCRP/IAPSO WG 136 - The Climatic Implications of the Greater Agulhas System, organized a conference on The Agulhas system and its role in changing Ocean Circulation, Climate, and Marine Ecosystems. It was held in Stellenbosch, South Africa, in October 2012 and generated a great deal of excitement among participants, particularly among regional scientists, some of whom had not previously attended an international conference.

Over the years there have been a number of joint meetings with SCOR, and in 2017, during the IAPSO/IAMAS/IAGA assembly, IAPSO again joined forces with them to hold a special session for the SCOR/IOC-sponsored IIOE-2 (Second International Indian Ocean Expedition). This proved to be very successful, giving scientists from developing countries who were working in the project the opportunity to apply for IAPSO funding and attend an international conference that perhaps would have otherwise been impossible.

\subsection{The equation of state: EOS-80 and TEOS-10}

During the 1960s and 1970s traditional sampling techniques, requiring reversing thermometers for temperature measurements, as well as titration-based chemical analyses of water samples for salinity (so-called Chlorinity Salinity or Knudsen Salinity, with units of parts per thousand), were being replaced by newer techniques implemented by electronic instrumentation. These new instruments could be lowered into the ocean or moored to make near-continuous measurements in space or time. However, use of these new technologies raised many technical issues that needed to be solved. One important issue was that new methods for determining salinity and density had to be standardized to supersede old methods first developed in the early part of the 20th century.

Between 1964 and 1980 the Joint Panel on Oceanographic Tables and Standards developed EOS-80. This described (a) the definition of the Practical Salinity Scale 1978, PSS78 (UNESCO, 1981); and (b) the International Equation of State of Seawater 1980, EOS-80 (UNESCO, 1983). However, EOS-80 did not address several fundamental issues. First, since the EOS-80 algorithms are based on measurements of Standard Seawater, they are not well linked to the actual ocean. It was known even in the 1970s that the densities of real seawater could differ from their EOS-80 calculated values by as much as $0.020 \mathrm{~kg} \mathrm{~m}^{-3}$ in the open ocean (Lewis and Perkin, 1978) and that these differences were largest in the North Pacific because of the effects of added nutrients and inorganic carbon (Brewer and Bradshaw, 


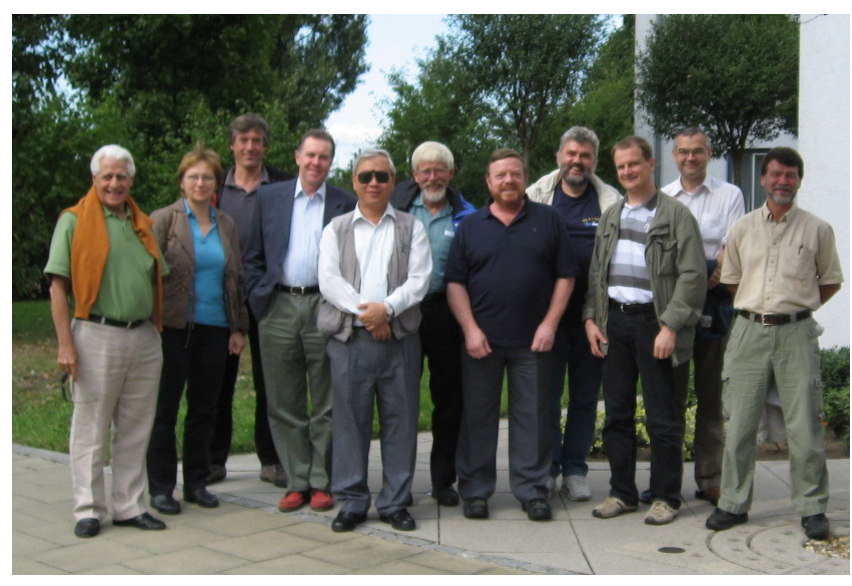

Figure 9. Members of WG 127 (source: Fig. 10 in Millero, 2010).

1975). Additionally, while thermodynamic relationships can be used to derive certain physical properties from measurements of other properties, the collected algorithms of EOS80 were thermodynamically inconsistent. In particular sound speed could be derived in two different ways using the EOS80 algorithms, from different specified correlation equations, with different numerical results.

Consequently in 2005 the SCOR/IAPSO Working Group 127 was established in order to examine the idea of defining seawater properties using a Gibbs function, which would enforce thermodynamic consistency for properties such as sound speed. The stated goal was merely to come up with recommendations in the form of a report and to write some review papers on the matter. At their first meeting in 2006, it was decided to introduce a new salinity variable that had mass fraction units and numerical values that actually reflected the best available estimates for their true values. This was achieved through the development of the Reference Composition and the Absolute Salinity (Millero et al., 2008). In essence the salinity concept was formalized using a carefully defined artificial seawater, which would in practice be most easily realized as a physical artefact by Standard Seawater. The idea that salinity involves a mass of ions and neutral molecules in solution and not the mass of dissolved solids (a distinction that had been poorly understood and/or mostly ignored in the past) was implicit in this process and led to the concept of Reference Composition Salinity. The Reference Composition Salinity is the mass fraction of the constituent inorganic ions and compounds in Reference Composition Seawater, and it can be calculated by summing up the molar concentrations of the constituents of Reference Composition Seawater, multiplied by their atomic weights.

In order to account for composition changes in real seawaters, a correction factor was needed. The eventual choice was to correct Reference Salinity for the composition variations that occur in real seawater by adding to it a Salinity Anomaly to estimate the Absolute Salinity. For Standard Seawater the best currently available estimate of Salinity Anomaly is zero. For real seawater, the Salinity Anomaly is almost always non-zero, and some practical recommendations were made at that time about how the Salinity Anomaly should be defined.

The connections between electrical conductivity, the mass fraction of solutes, and the specific volume of seawater is a very complicated subject, especially so because biogeochemical processes add material to seawater which is inherently less conductive than sea salt, and the chemical equilibria involved depend on temperature and pressure. Consideration of these issues gives rise to several different types of $\mathrm{Ab}$ solute Salinity, and the connections between them were put on a firm footing by the two papers Pawlowicz (2010) and Pawlowicz et al. (2011), with Wright et al. (2011) being a very readable summary of the issues involved. Since density (or specific volume) is the property of primary interest in physical oceanography, it was decided that the Absolute Salinity of real seawater should be defined to be the mass fraction salinity (on the Reference Composition Scale) of Reference Composition Seawater with the same density as that of the sample being measured at a specified temperature and pressure (Wright et al., 2011). Ongoing research on the meaning and measurement of Absolute Salinity is described in Feistel et al. (2016) and Pawlowicz et al. (2016).

The TEOS-10 (IOC et al., 2010) approach of using thermodynamic potentials to describe the properties of seawater, ice, and moist air means that it is possible to derive many more thermodynamic properties than were available from EOS-80. The seawater properties entropy, internal energy, enthalpy, and particularly potential enthalpy were not available from EOS- 80 but are central to accurately calculating the transport of heat in the ocean and hence the air-sea heat flux in the coupled climate system. The incorporation of the spatial and temporal variations of the relative composition of sea salt means that the baroclinic ocean transports can be evaluated more accurately than was possible by using only Practical Salinity.

\section{IAPSO and societal issues}

Over the years, several of IAPSO's activities have underpinned the climate projections of IPCC. In particular, IAPSO's support of work on sea level have made major contributions to all of the IPCC research assessments. Without the Standard Seawater Service to assure the precision of salinity measurements, the detection of subtle basin-wide changes as indicators of changes in the earth's hydrological cycle would not be possible. More recently the outcomes of working groups on ocean mixing and TEOS-10 have influenced the climate models used in the IPCC's 5th assessment in 2014 and continue to influence oceanography worldwide.

In addition, in November 2015, the IUGG secretary general Alik Ismail-Zadeh suggested to the president of IAPSO, 


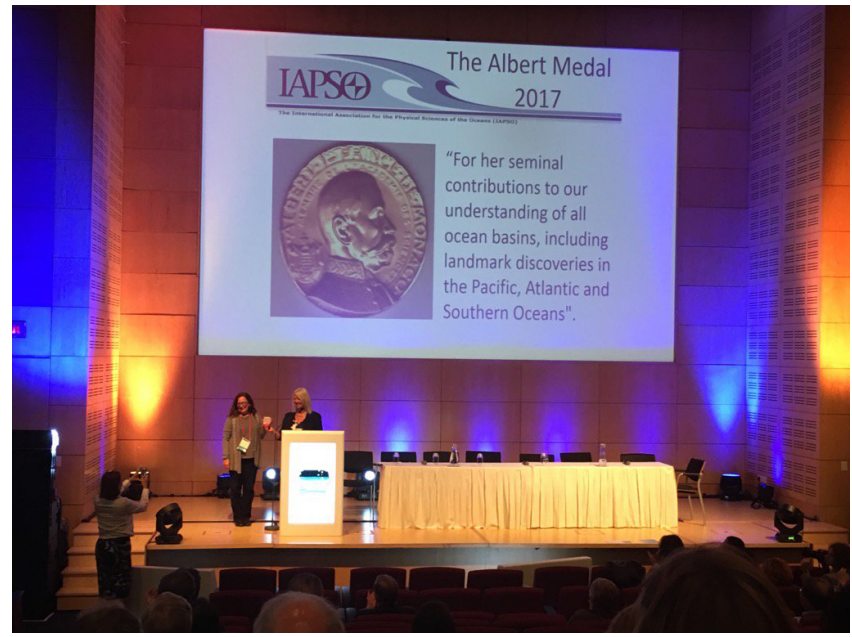

Figure 10. Presentation of the 2017 Prince Albert I Medal to Professor Lynne Talley (source: IAPSO archives).

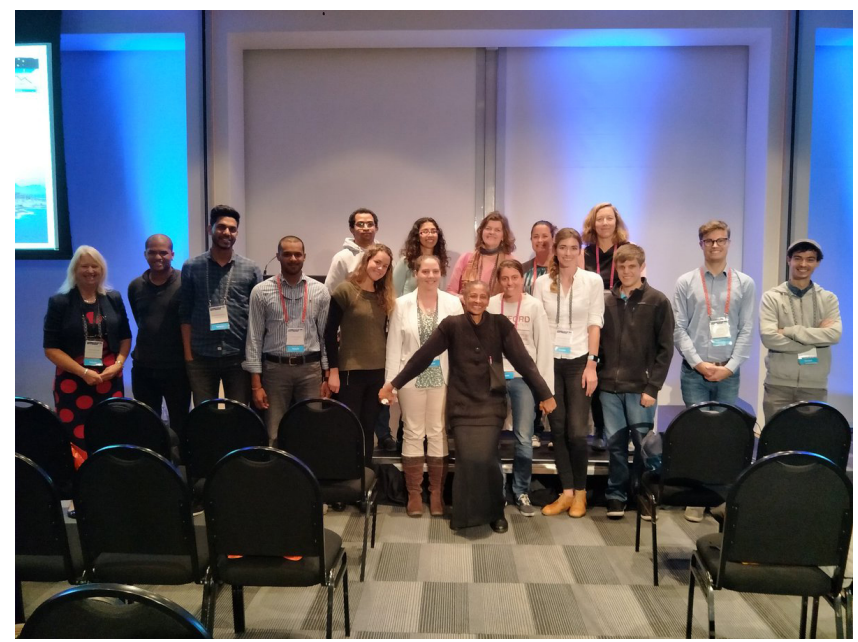

Figure 11. The IIOE-2 ECS meeting in Cape Town (source: IAPSO archives).

Denise Smythe-Wright, that she instigate an initiative in response to the marine science issues raised by the Group of Seven (G7) science ministers in the communique arising from their meeting in October 2015. The G7 countries have outstanding oceanographic capabilities and are well placed not only to continue to provide world leadership in marine environmental research, but also to use the research outcomes for their wider socio-economic benefit. Realizing that this was not just an IAPSO initiative, the president of IAPSO approached Peter Burkill, president of SCOR at the time, and together they mustered 14 international experts to address the following issues: marine litter, ocean acidification, biodiversity loss, deoxygenation, ocean warming, ecosystem degradation, and deep-sea mining. This became the ad hoc IUGG/IAPSO/SCOR working group of experts on the Future of the Ocean and its Seas (2015-2016), which resulted in the report Future of the Ocean and its Seas: a non-governmental scientific perspective on seven marine research issues of $G 7$ interest (Williamson et al., 2016). It was submitted to the G7 science ministers prior to their meeting in Japan, in May 2016.

\section{The future}

Back in 1975, there was some discussion about the benefit and future of the "Big Meeting" and such discussion continue today. However, IAPSO believes that the free and easy atmosphere of IAPSO assemblies, whether in conjunction with other associations or during the IUGG general assemblies, still provides the best possible environment for scientific discussion and the bringing together of ideas. In the 1970s IAPSO was very mindful of the growth of oceanography due to the explosion in technical development, resulting in a wealth of data and the idea that oceanography was one of the fastest-growing areas of science. We now have a plethora of autonomous systems and vehicles and so oceanography is again riding high. In its 100 years IAPSO has become the organization for oceanographic standards and services and with the growth in new systems there is now more than ever a need for calibration and inter-comparison, and IAPSO's aim for the future is to build on its reputation and take this aspect of its work forward. This does not mean we will lose sight of our biannual assemblies or funding for workshops and in support of scientists from developing countries.

As the Association approaches it centenary, it is interesting to note that it is no longer a male-dominated organization. The second female president, Denise Smythe-Wright, was appointed in 2015 and 5 out of 11 of the 2015-2019 executive committee members are female; in 2017 IAPSO had its first female Prince Albert I Medal winner - Lynne Talley. Our sights are now looking to encourage young scientists into the Association, and in the last year we have set up our Early Career Scientists network (ECS) and instigated Early Career Scientist medals which will be awarded for the first time in 2019. We believe we are well placed to face the next 100 years.

Data availability. No data sets were used in this article.

Competing interests. The authors declare that they have no conflict of interest.

Special issue statement. This article is part of the special issue "The International Union of Geodesy and Geophysics: from different spheres to a common globe" (https://www.hist-geo-space-sci. net/special_issue996.html). It is not associated with a conference. 
Review statement. This paper was edited by Alik Ismail-Zadeh and reviewed by Eugene Morozov and one anonymous referee.

\section{References}

Berget, A. (Ed.): Commission internationale pour l'exploration scientifique de l'Atlantic (International Commission for the Scientifique Exploration of the Atlantic), Procès-Verbal de la réunion (meeting report) du 31 mars 1910, à Monaco, Bulletin de l'Institut Océanographique, No. 176, Monaco, 1-14, 1910.

Brewer, P. G. and Bradshaw, A.: The effect of non-ideal composition of seawater on salinity and density, J. Mar. Res., 33, 157175, 1975.

Commission Hydrographique Suédoise: Proposition sur les limites de la région à explorer, Conférence internationale pour l'Exploration de la Mer réunie à Stockholm, XXXI-XXXII, Imprimerie K. L. Beckman, Stockholm, XXXI-XXXII, 1899.

Charnock, H: Marine science, Organising the study of the oceans, Mar. Policy, 8, 120-136, 1984.

Culkin, F. and Smed, J.: The history of standard seawater, Oceanol. Ac., 2, 355-364, 1979.

Dittmar, W: Report on researches into the composition of ocean water, collected by H.M.S. Challenger, Challenger Repts, Phys. Chem., 1, 1-251, 1884.

Feistel, R., Wielgosz, R., Bell, S. A., Camões, M. F., Cooper, J. R., Dexter, P., Dickson, A. G., Fisicaro, P., Harvey, A. H., Heinonen, M., Hellmuth, O., Kretzschmar, H-J., Lovell-Smith, J. W., McDougall, T. J., Pawlowicz, R., Ridout, P., Seitz, S., Spitzer, P., Stoica, D., and Wolf, H.: Metrological challenges for measurements of key climatological observables: Oceanic salinity and $\mathrm{pH}$, and atmospheric humidity, Part I Overview. Metrologia, 53, R1-R11, 2016.

Gutenberg, B.: Changes in sea level, postglacial uplift, and mobility of the earth's interior, Bull. Geol. Soc. Am., 52, 721-772, 1941.

Holgate, S. J., Matthews, A., Woodworth, P. L., Rickards, L. J., Tamisiea, M. E., Bradshaw, E., Foden, P. R., Gordon, K. M., Jevrejeva, S., and Pugh, J.: New data systems products at the Permanent Service for Mean Sea Level, J. Coast. Res., 29, 493-504, doi:10.2112/JCOASTRES-D-12-00175.1, 2013.

IAPO: Monthly and annual mean heights of sea level up to and including the year 1936, in: Publication Scientifique No. 5, Report of the International Association of Physical Oceanography, Liverpool, 256 pp., 1940. (All reports in this series may be obtained via https://www.psmsl.org, last access: 19 March 2019).

IOC, SCOR and IAPSO: The international thermodynamic equation of seawater: Calculation and use of thermodynamic properties, Intergovernmental Oceanographic Commission, Manuals and Guides No. 56, UNESCO (English), 196 pp, available at: http://www.teos-10.org/pubs/TEOS-10_Manual.pdf (last access: 19 March 2019), 2010.

Lewis, E. L. and Perkin, R. G.: Salinity, its definition and calculation, J. Geophys. Res., 83, 466-478, 1978.
Maury, M. F.: The Physical Geography of the Sea, Sampson Low and Son, London, 287 pp., 1855.

Millero, F. J: History of the equation of state of seawater, Oceanography, 23, 18-33, https://doi.org/10.5670/oceanog.2010.21, 2010.

Millero, F. J., Feistel, R., Wright, D. G., and McDougall, T. J.: The composition of Standard Seawater and the definition of the Reference-Composition Salinity Scale, Deep-Sea Res. I, 55, 50 $72,2008$.

Nature Geoscience Editorial: Save our sea-level observations, Nat. Geosci., 6, p. 987, https://doi.org/10.1038/ngeo2035, 2013.

Pawlowicz, R.: A model for predicting changes in the electrical conductivity, practical salinity, and absolute salinity of seawater due to variations in relative chemical composition, Ocean Sci., 6, 361-378, https://doi.org/10.5194/os-6-361-2010, 2010.

Pawlowicz, R., Wright, D. G., and Millero, F. J.: The effects of biogeochemical processes on oceanic conductivity/salinity/density relationships and the characterization of real seawater, Ocean Sci., 7, 363-387, https://doi.org/10.5194/os-7-363-2011, 2011.

Pawlowicz, R., Feistel, R., McDougall, T. J., Ridout, P., Seitz S., and Wolf, H.: Metrological challenges for measurements of key climatological observables: Part 2, Oceanic salinity, Metrologia, 53, R12-R25, 2016.

Pettersson, O.: Letter of 12 November 1921 to C. F. Drechsel, in: Rigsarkivet, Copenhagen, No. 10, 649, Box 16, File 1.D, Gen. II, 1921.

Procès-Verbaux No 1: Association d'Océanographie Physique: Cinquième Assemblée Générale réunie à Lisbonne, September 1933, 1-80, 1934.

Rossiter, J. R.: The work of the Permanent Service for Mean Sea Level, Int. Hydrograph. Rev., 40, 85-89, 1963.

Smed, J.: ICES and the new organizations - competition or cooperation?, History of Oceanography, 19, 32-42, 2007.

UNESCO: The Practical Salinity Scale 1978 and the International Equation of State of Seawater 1980, UNESCO technical papers in marine science, 36, 25 pp., 1981.

UNESCO: Algorithms for computation of fundamental properties of seawater, UNESCO technical papers in marine science, 44, 53 pp., 1983.

Williamson, P., Smythe-Wright, D., and Burkill, P. (Eds.): Future of the Ocean and its Seas: a non-governmental scientific perspective on seven marine research issues of G7 interest, available at: http: //www.iugg.org/policy/Report_FutureOcean_G7_2016.pdf (last access: 19 March 2019), 2016.

Woodworth, P. and Rickards, L.: Eighty years of the Permanent Service for Mean Sea Level, Ocean Challenge, 20, 18-19, 2014.

Wright, D. G., Pawlowicz, R., McDougall, T. J., Feistel, R., and Marion, G. M.: Absolute Salinity, "Density Salinity" and the Reference-Composition Salinity Scale: present and future use in the seawater standard TEOS-10, Ocean Sci., 7, 1-26, https://doi.org/10.5194/os-7-1-2011, 2011. 